\title{
A Correlational Study Between Sentence Structure Mastery, Self- Esteem, And Reading Skill And Its Contribution In Lesson Plan Development
}

\author{
Arief Eko Priyo Atmojo, Abdul Asib, Muhammad Asrori \\ English Education Department \\ Teacher Training and Education Faculty \\ Sebelas Maret University of Surakarta
}

Email: arivincible@yahoo.co.id

\begin{abstract}
The objectives of this research are to find out the correlation between (1) sentence structure mastery and reading skill; (2) self-esteem and reading skill; and (3) sentence structure mastery, self-esteem, and reading skill. This research used quantitative method, that is, correlational study. The results show that in the level of significance of $\alpha=0.05$ there is a positive and significant correlation between (1) sentence structure mastery and reading skill ( $\left.\quad=0.8058>\mathrm{r}_{\mathrm{t}}=0.423\right) ;(2)$ self-esteem and reading skill $(=0.5178>$ $\mathrm{r}_{\mathrm{t}}=0.423$ ); and (3) sentence structure mastery, self-esteem, and reading skill ( $\quad=0.8384$ and $\quad=22.47>=4.35)$. Both sentence structure mastery and self-esteem give $70.29 \%$ effective contribution to reading skill. Therefore, it is suggested that teachers create innovation in utilizing any interesting activity and develop lesson plan which enable students to acquire sentence structure knowledge easily and increase their self-esteem.
\end{abstract}

Keywords: sentence structure mastery, self-esteem, reading skill

\section{INTRODUCTION}

A student must have good reading comprehension to understand academic text; moreover, it will be best if the student master critical reading, not only reading comprehension. Reading skill is really important for students because it is a skill which enables them to acquire new knowledge. Byrnes and Wasik (2009: 171) argue "it is very important to take care of reading skill development because it has strong and direct connection which affects academic level and professional success which will be enjoyed by an individual".

The reason of why reading skill is taught from elementary school to senior high school in Indonesia is because reading is a monumental task according to required effort needed to read for meaning in real time academic situations even the reader who learns English language is an able decoder in English (Lems, Miller, and Soro, 2010: 170-171). Moreover, there are other problems to be solved in reading skill by English language learners. Those problems are the difficulty to get the advantages of the phonological loop due to the opacity of English orthography, incomplete knowledge of English syntax and its grammar patterns, and the limits of working memory. In fact, we need effort to struggle with sentences in a new language because reading takes much cognitive energy. Therefore, it is a difficult job to retain the gist of previous sentences in a paragraph or previous paragraphs in 
working memory as we move from the first sentence to the whole text. Even decoding is easy to do, it still becomes much harder task to read a whole text and construct meaning from it as we read in a new language. This phenomenon could be described as a real-time "delay" (Lems, Miller, and Soro, 2010: 171).

As mentioned before, reading skill needs good understanding of English syntax and its grammar patterns. Thus, English language learners must master those two aspects as well. Moreover, sentence structure is a fundamental aspect that should be mastered by English language learners because it will strengthen their comprehension on English texts. Radford (2009: 39) states "syntactic structure is the way of how words are combined together to generate phrases and sentences". Accordingly, sentence structure is the way of how words and phrases are arranged altogether to create grammatically correct sentences.

It is because text is arranged from the collection of sentences so that readers must master sentence structure as well to comprehend the whole text and to construct meaning from it. According to Willis (2009: 29), what is meant by structure here is the way of items (words and phrases) combined to create larger units. In addition, McGuinness (2005: 329) defines that syntax is the structural organization of words in a clause or sentence of a particular language. Especially in English, syntax functions as word order in a sentence.

Another factor which may affect one ${ }^{\text {ee }}$ reading skill is self-esteem. It is because reading is a mentally active activity which needs good psychological condition. According to McKay and Fanning (2000: 1), self-esteem is essentially needed by a person for psychological survival. An enormously painful life can be caused by the absence of self-worth which results in many fundamental needs going unmet.

There are some benefits achieved by having high self-esteem. As stated by Branden (1992: vii), self-esteem is a person "s appropriateness to life and fulfilment to the requirements of life. A person who has high self-esteem will think confidently and cope with the fundamental challenges of life. In the other hand, Brown and Marshall (2002: 7) argue that people ${ }^{\text {ee }}$ quality is not represented by selfesteem. But, what people think they are like is strongly related to self-esteem. In short, people having high self-esteem think that they are more attractive, more intelligent, and better liked than people having low self-esteem.

Some researchers have arguments about the correlation between reading skill and self-esteem. Soureshjani and Naseri (2011: 1317) state that relationship between EFL learners ${ }^{\text {ee }}$ self-esteem and their reading performance is not so strong although those two variables have significant relationship. In contrast, Soureshjani and Naseri (2011: 1317) find many previous studies which state strong correlation between the same variables (self-esteem and reading skill). Any academic performance improvement is not reliably caused by high self-esteem. It is possible that occupational success improves people ${ }^{e e}$ s self-esteem rather than the reverse. (Baumeister et al., 2003: 36). According to Hisken (2011: 24-25), having low reading ability can make a person to have low self-esteem. In reverse, students ${ }^{\text {ee }}$ reading level (especially reading comprehension) can directly be affected by their self-esteem. In short, self-esteem 
gives contribution to students ${ }^{\text {ee }}$ reading skill.

Based on the explanation above, the aims of this study are to find out the correlation between (1) sentence structure mastery and reading skill; (2) self-esteem and reading skill; and (3) sentence structure mastery, self-esteem, and reading skill.

\section{RESEARCH METHODS}

The method used in this study is correlation method. Gall, Gall, and Borg (2003: 20) define correlational research as the studies in which the purpose is to discover relationships between variables through the use of correlational statistics. Correlational research designs are used for two major purposes: (1) to explore causal relationship between variables and (2) to predict scores on one variable from research participants ${ }^{\text {ee }}$ scores on other variables (Gall, Gall, and Borg, 2003: 325). Correlation method is chosen in this study because the researcher wants to study whether there is correlation between three variables in correlation coefficient based on quantitative research method.

Two kinds of variable exist in this study. Those variables are called as dependent variable and independent variable. Reading skill becomes the dependent variable (Y) while the independent variables are sentence structure mastery $\left(\mathrm{X}_{1}\right)$ and self-esteem $\left(\mathrm{X}_{2}\right)$.

This study was carried out in a senior high school which is located in Katelan, Tangen, Sragen 57261. The research covers pre-research, data collection and analysis, and final report writing.

The population was the tenth grade IPA (Ilmu Pengetahuan Alam) students consisting of three classes. The total number of the students is 67 students. The sample was 22 students taken by cluster random sampling technique.

In this study, test and non-test technique were used to obtain the data of research. A multiple-choice test was used to collect the data of reading skill and sentence structure mastery. Meanwhile, the students $^{\text {ee }}$ self-esteem was investigated using a questionnaire. All instruments have been tried out to find the validity and reliability of the items.

There are some pre-requirement tests before hypothesis testing. The prerequirement tests consist of normality test, linearity of regression test, and significance of regression test. After prerequirement tests are done, the data are ready to be analyzed to test the hypothesis. The data were analyzed using Pearson Product Moment Formula and Multiple Linear Regression. Pearson Product Moment Formula was used to find out the correlation between two variables $\left(\mathrm{X}_{1}-\mathrm{Y} /\right.$ $\mathrm{X}_{2}$-Y). Meanwhile, Multiple Linear Regression was used to figure out the correlation between two independent

variables simultaneously and one dependent variable $\left(\mathrm{X}_{1}, \mathrm{X}_{2}-\mathrm{Y}\right)$.

\section{RESEARCH FINDINGS AND DISCUSSION}

From the simple correlation computation of $\mathrm{X}_{1}$ and $\mathrm{Y}$, the value of coefficient of correlation $\left(r_{o}\right)$ is 0.8058 and coefficient of determination $\left(r_{o}{ }^{2}\right)$ is 0.6493 . The value of (0.8058) is consulted to $r$-table at the significance level $\alpha=0.05$ for $\mathrm{n}=22(0.423)$. Because the result shows that $\quad(0.8058)$ is higher than $r t(0.423)$ or $(0.8058)>r_{t}(0.423)$, it means that $r_{O}$ is significant. It means that the first 
hypothesis saying there is a positive correlation between sentence structure mastery $\left(\mathrm{X}_{1}\right)$ and reading skill $(\mathrm{Y})$ is accepted. $r_{o}{ }^{2}(0.6493)$ is coefficient of determination, meaning that $64.93 \%$ variance of reading skill $(\mathrm{Y})$ is determined by sentence structure mastery $\left(\mathrm{X}_{1}\right)$ and $35.07 \%$ variance of reading skill $(\mathrm{Y})$ is determined by other factors.

From the simple correlation computation of $\mathrm{X}_{2}$ and $\mathrm{Y}$, the value of coefficient of correlation $\left(r_{O}\right)$ is 0.5178 and coefficient of determination $\left(r_{O}{ }^{2}\right)$ is 0.2682 . The value of (0.5178) is consulted to $r$-table at the significance level $\alpha=0.05$ for $\mathrm{n}=22(0.423)$. Because the result shows that $\quad(0.5178)$ is higher than $r_{t}(0.423)$ or $(0.5178)>r_{t}(0.423)$, it means that $r_{O}$ is significant. It means that the second hypothesis saying there is a positive correlation between self-esteem $\left(\mathrm{X}_{2}\right)$ and reading skill (Y) is accepted. $r_{o}{ }^{2}(0.2682)$ is coefficient of determination, meaning that $26.82 \%$ variance of reading skill (Y) is determined by self-esteem ( $\left.\mathrm{X}_{2}\right)$ and $73.18 \%$ variance of reading skill $(\mathrm{Y})$ is determined by other factors.

From the computation of multiple linear regression test, the result shows that the value of the coefficient $=-18.93$, $=0.94$, and $=0.36$. Therefore, the multiple regression equation of $\mathrm{Y}$ on $\mathrm{X}_{1}$ and $\mathrm{X}_{2}$ becomes $\hat{\mathrm{Y}}=-18.93+0.94 \mathrm{X}_{1}+$ $0.36 X_{2}$. Moreover, the computation of multiple linear regression test also shows that the value of is 22.47 . Then, the value of (22.47) is consulted to $F$-table at the significance level $\alpha=0.05$ and the degree of freedom (d.f.) for 1:20 (4.35). Because the result shows that (22.47) is higher than $(1,20)$ for $\alpha=0.05$ (4.35), or $(22.47)>(4.35)$, it means that the multiple linear regression is significant. It means that there is a positive correlation between sentence structure mastery $\left(\mathrm{X}_{1}\right)$ and self-esteem $\left(\mathrm{X}_{2}\right)$ simultaneously and reading skill (Y). $R^{2}(0.7029)$ is the coefficient of determination, meaning that $70.29 \%$ variance of reading skill $(\mathrm{Y})$ is determined by sentence structure mastery $\left(\mathrm{X}_{1}\right)$ and self-esteem $\left(\mathrm{X}_{2}\right)$ and the rest, $29.71 \%$ variance, is determined by other factors.

Each of the independent variables (sentence structure mastery and selfesteem) gives contribution toward the dependent variable (reading skill). The effective contribution of each variable can be concluded as follows: (1) sentence structure mastery $\left(\mathrm{X}_{1}\right)$ contributes $61.63 \%$ to reading skill $(\mathrm{Y})$; (2) self-esteem (X2) contributes $8.66 \%$ to reading skill $(\mathrm{Y})$; and sentence structure mastery $\left(\mathrm{X}_{1}\right)$ and selfesteem ( $\left.\mathrm{X}_{2}\right)$ simultaneously contribute $70.29 \%$ to reading skill (Y).

The results show that there is significant and positive correlation between sentence structure mastery, selfesteem, and reading skill. The description of the correlation between sentence structure mastery, self-esteem, and reading skill is the following.

Sentence structure is a fundamental aspect that should be mastered by English language learners because it will strengthen their reading skill. Lems, Miller, and Soro (2010: 171) argue that incomplete knowledge of sentence structure is one of the problems which must be solved in reading skill by English language learners. According to Nation and Snowling (2000) in Morvay (2012: 417), syntactic awareness and reading comprehension have a strong correlation. In addition, Azizifar (2011) states that the awareness of sentence structures and explicit teaching of 
grammatical structures can significantly improve high school students ${ }^{\text {ee }}$ reading comprehension performance. It proves that there is significant relationship between sentence structure awareness and reading comprehension.

Morvay (2012: 417) also argues that the higher the English syntax mastery of learners is, the greater their chances are to be skilful readers. That is why sentence structure mastery becomes an important aspect to increase students ${ }^{\text {ee }}$ reading skill. Radford (2009: 39) states "syntactic structure is the way of how words are combined together to generate phrases and sentences". Accordingly, sentence structure is the way of how words and phrases are arranged altogether to create grammatically correct sentences. It is because text is arranged from the collection of sentences so that readers must master sentence structure as well to comprehend the whole text and to construct meaning from it. In other words, the more people master sentence structure the better their reading skill will be.

Having high self-esteem is also an important thing in reading. Having high self-esteem will help students to cope with reading challenges because reading is a monumental task according to required effort which is needed to read for meaning in real time academic situations. Soureshjani and Naseri (2011: 1317) find many previous studies which state strong correlation between self-esteem and reading skill. Gee (1999) in Soureshjani and Naseri (2011: 1313) argues about the relationship between self-esteem and reading skill by enlightening affective factor and reading skill which have an important relationship. Studentse ${ }^{\text {ee }}$ reading level (especially reading comprehension) can directly be affected by their self- esteem. There is a positive correlation between self-esteem and reading ability, reading level, and academic achievement. Self-esteem can directly increase students ${ }^{\text {ee }}$ reading level, in particular their reading comprehension. A high level of selfesteem functions to fight against anxiety. So, students having high self-esteem do not experience struggle with reading challenges (Hisken, 2011).

Torgesen (2006: 3) mentions

some factors affecting reading comprehension which are: 1) accurate and fluent word reading skills; 2) oral language skills (vocabulary, linguistic comprehension); 3) extent of conceptual and factual knowledge; 4) knowledge and skill in use of cognitive strategies to improve comprehension or repair it when it breaks down; 5) knowledge of text structure and genre; 6) reasoning and inferential skills; and 7) motivation to understand and interest in task and material. All of these factors include linguistic and cognitive aspects of language and affective features.

Some previous studies conducted by Bentin, Deutsch, and Liberman (1990); Demont and Gombert (1996); and Waltzman and Cairns (2000) in Morvay (2012: 417) gave result in statement that linguistic knowledge, especially insufficient syntactic abilities, caused poor reading comprehension. As consequence, strong syntactic abilities are very important to have efficient reading comprehension. It is also stated that the level of English syntax mastery which one possesses gives impact on his or her English reading skill. Thus, students must master sentence structure well to achieve excellent reading skill.

Besides considering the mastery of sentence structure, students should have 
high self-esteem in reading. This is aimed at helping them to cope with reading challenges. By having high self-esteem, students will not get struggle with reading challenges. In general, Krashen (1992) in Huang (2012: 1521) states that having anxiety or low self-esteem will make language acquirer difficult in learning foreign language. Huang (2012: 1525) adds that both teachers and students must give special attention to affective factors like anxiety and self-esteem. Hisken (2011: 6-7) also agrees that there is a correlation between students ${ }^{\text {ee }}$ self-esteem and their reading ability, reading level, and academic achievement. Students who have low self-esteem are not confident enough to try challenges in their reading which results in the tendency to have lower reading ability. They do not have enough confidence in themselves or their ability to try new types of reading materials, authors, or genres. Therefore, sentence structure mastery and self-esteem are considered as important factors in improving reading skill.

Thus, it is clear that both sentence structure mastery and self-esteem simultaneously give positive contribution toward reading skill. Considering that sentence structure mastery and self-esteem give contribution to reading skill, teachers need to create activities and arrange lesson plan which can increase students ${ }^{\text {ee }}$ sentence structure mastery and self-esteem without omitting the goal of the lesson. Besides, students should also give more attention on sentence structure mastery and increase their self-esteem. Both teachers and students are suggested to create positive atmosphere in English learning so students can learn English well. Therefore, students ${ }^{\text {ee }}$ reading skill will increase.

\section{CONCLUSION, IMPLICATION, AND SUGGESTION}

From the results above, it can be concluded that there is a positive correlation between sentence structure mastery $\left(\mathrm{X}_{1}\right)$ and reading skill (Y) $\left(\quad=0.8058>r_{t}=0.423\right)$. The relative contribution of sentence structure mastery $\left(\mathrm{X}_{1}\right)$ toward reading skill $(\mathrm{Y})$ is $87.68 \%$ while the effective contribution is $61.63 \%$. It means that the increase of sentence structure mastery $\left(\mathrm{X}_{1}\right)$ will be followed by the increase of reading skill (Y).

There is a positive correlation between self-esteem $\left(\mathrm{X}_{2}\right)$ and reading skill (Y) $\left(=0.5178>r_{t}=0.423\right)$. The relative contribution of self-esteem $\left(\mathrm{X}_{2}\right)$ toward reading skill $(\mathrm{Y})$ is $12.32 \%$ while the effective contribution is $8.66 \%$. It means that the increase of self-esteem $\left(\mathrm{X}_{2}\right)$ will be followed by the increase of reading skill (Y).

There is positive correlation between sentence structure mastery $\left(\mathrm{X}_{1}\right)$ and self-esteem ( $\left.\mathrm{X}_{2}\right)$ simultaneously and reading skill (Y) ( =0.8384 and $=22.47>=4.35)$. The contribution of sentence structure mastery $\left(\mathrm{X}_{1}\right)$ and selfesteem $\left(\mathrm{X}_{2}\right)$ simultaneously toward reading skill (Y) is $70.29 \%$. It means that the increase of sentence structure mastery $\left(\mathrm{X}_{1}\right)$ and self-esteem $\left(\mathrm{X}_{2}\right)$ will be followed by the increase of reading skill (Y).

Therefore, both teachers and

students must give special attention to sentence structure mastery and selfesteem. Teachers must create meaningful activities and arrange lesson plan which can increase students ${ }^{\text {ee }}$ sentence structure mastery and self-esteem. In addition, teachers and students should also create positive atmosphere in English class without omitting the goal of the lesson in 
order to increase students ${ }^{\text {ee }}$ self-esteem and to improve their sentence structure mastery.

To improve students ${ }^{\text {ee }}$ sentence structure mastery, the teachers should have innovation in utilizing any interesting activity and develop lesson plan which enable students to acquire sentence structure knowledge easily. Teachers must also be able to (1) encourage the students to have excellent reading skill; (2) manage the class situation by decreasing students ${ }^{\text {ee }}$ fear and worry, increasing respect to each other, and treating each other well; and (3) appreciate and give rewards to studentse academic achievement. In the other hand, students must also work hard to improve their sentence structure mastery and selfesteem.

\section{REFERENCES}

Azizifar,L-Akbar. (2011). The relationship between sentence structure awareness and Iranian high school studentse performance in reading comprehension. NileTESOL 2011 Conference Proceedings. Retrieved from http:// www3.aucegypt.edu/auctesol/Def ault.aspx ?issueid $=\mathrm{dc} 82 \mathrm{a} 931$ ec50-4ac8-98a34878b73f0399\&aid $=50$ efc 845 0afe-4ef8-a800-c3bbb031ed67 on June 4, 2014.

Baumeister, Roy F., et al. (2003). Does high self-esteem cause better performance, interpersonal success, happiness, or healthier lifestyles? Psychological Science in the Public Interest, 4(1), 1-44, May 2003.
Branden, Nathaniel. (1992). The power of self-esteem. Florida: Health Communications.

Brown, Jonathon D. and Marshall, Margaret A. (2002). Self-esteem: It"s not what you think. Under Review Article. Seattle: University of Washington.

Byrnes, James P. and Wasik, Barbara A. (2009). Language and literacy development: What educators need to know. New York: The Guilford Press.

Gall, Meredith D., Gall, Joyce P., and Borg, Walter R. (2003). Educational research: An introduction ( $7^{\text {th }}$ ed.). Boston: Pearson Education.

Hisken, Loree J. (2011). The correlation between self-esteem and student reading ability, reading level, and academic achievement. A Thesis, December 2011. Missouri: University of Central Missouri.

Huang, Qian. (2012). Study on correlation of foreign language anxiety and English reading anxiety. Theory and Practice in Language Studies, 2(7), 1520-1525, July 2012. Finland: Academy Publisher.

Lems, Kristin., Miller, Leah D., and Soro, Tenena M. (2010). Teaching reading to English language learners: Insights from linguistics. New York: The Guilford Press.

McGuinness, Diane. (2005). Language development and learning to read: The scientific study of how language development affects 
reading skill. Cambridge: The MIT Press.

McKay,

Matthew

and

Fanning,

(2000).

esteem

Oakland: New Harbinger
Publications.

Morvay, Gabriella. (2012). The relationship between syntactic knowledge and reading comprehension in EFL learners. Studies in Second Language Learning and Teaching, 2(3), 415-438, October 2012.

Radford, Andrew. (2009). An introduction to English sentence structure. Cambridge: Cambridge University Press.

Soureshjani, Kamal Heidari and Naseri, Noushin. (2011). An investigation into the relationship between selfesteem, proficiency level, and the reading ability of Iranian EFL language learners. Journal of

Language Teaching and Research, 2(6), 1312-1319, November 2011. Finland: Academy Publisher.

Torgesen, Joseph K. (2006). Factors that influence reading comprehension: Developmental and instructional considerations. Retrieved from http://www.fcrr.org/science/pdf/to rgesen/Core_knowledge.pdf on November 27, 2014.

Willis, Dave. (2009). Rules, patterns, and words: Grammar and lexis in English language teaching. Cambridge: Cambridge University Press. 
